\title{
4. MARINE SEISMIC SYSTEM (MSS) PROJECT ${ }^{1}$
}

\author{
J. A. Ballard, Naval Ocean Research and Development Activity ${ }^{2}$
}

\section{INTRODUCTION}

Deep Sea Drilling Project (DSDP) Leg 88 was funded by the Defense Advanced Research Projects Agency (DARPA) in order to install and test a borehole seismometer's quantitative capabilities as a potential nuclear test/earthquake discriminator. In addition to the principal purpose, the following collateral scientific objectives, for which borehole seismic data are applicable, were defined:

1. Obtain data from a wide range of earthquake magnitudes, first motions, and focal depths which will help to clarify processes associated with subduction such as defining possible areas of tensional, compressional, and strike-slip faulting.

2. Determine the magnitude of changes of seismic properties of the oceanic crust with increasing age by establishing more accurate epicentral locations and by recording signals from events whose propagation paths are undistorted by seamount chains or island roots.

3. Measure signal absorption and propagation characteristics of both long-period and short-period body and surface waves.

4. Determine plate structure near the site using seismic refraction.

5. Evaluate source mechanisms within regional distances of an actively subducting plate boundary.

6. Measure anisotropy of the crust and upper mantle and anisotropic variations within crustal layers. Independent evidence suggests that crustal and upper mantle compressional-wave velocities have azimuthal variations as large as $0.9 \mathrm{~km} / \mathrm{s}$ near an active margin. Studies of variations in surface wave dispersion and refracted body wave traveltimes from many directions within the same area may generate information pertaining to the magnitude, mechanism, and direction of convective motions at various depths.

7. Determine the relationship of seismic background noise beneath the seafloor as a function of such param-

\footnotetext{
${ }^{1}$ Duennebier, F. K., Stephen, R., Gettrust, J. F., et al., Init. Repts. DSDP, 88: Washington (U.S. Govt. Printing Office).

2 Address: Naval Ocean Research and Development Activity, NSTL, MS 39529.
}

eters as bottom currents, tidal cycles, storms, convection, heat flow, sediment thickness, and lithification.

8. Measure elastic and rheological properties of converging plates.

9. Obtain long-term borehole temperature measurements which will permit determination of steady state heat-flow rates or the amount and direction of water flow in the hole.

Funding for collateral scientific studies and the support ship (USNS De Steiguer) was provided by the Naval Ocean Research and Development Activity (NORDA), the Office of Naval Research (ONR), and DARPA.

\section{OPERATIONS}

The original operational plan called for the deployment of the MSS sensor in oceanic crust at Site 581, about 720 miles east of Hokkaido, Japan, and the Hawaii Institute of Geophysics (HIG) borehole seismometer in a nearby drill hole. The Woods Hole Oceanographic Institution (WHOI) borehole hydrophone was to be deployed in the event that one of the other systems failed.

Specialized borehole instrumentation installation equipment, described in Volume 78B of the Initial Reports of DSDP (Hyndman, Salisbury, et al., 1984), was installed aboard ship on 18-19 August. The Challenger began drilling at Site 581 on 25 August and abandoned the hole on 27 August when the drill pipe broke about $0.5 \mathrm{~m}$ above the bottom hole assembly.

The spare re-entry cone was assembled and a new hole begun on 29 August. The hole was drilled to a total depth of $375 \mathrm{~m}$ sub-bottom but was lost when the $113 / 4$-in. casing could not be released because of equipment malfunction. The casing and the bottom hole assembly were severed by explosive charge. Further efforts to install the MSS in the northwest Pacific were abandoned.

MSS equipment was off loaded in Yokohoma, Japan and shipped to Wellington, New Zealand for use on Leg 91.

\section{REFERENCE}

Hyndman, R., Salisbury, M., et al., 1984. Init. Repts. DSDP, 78B: Washington (U.S. Govt. Printing Office).

Date of Initial Receipt: 3 August 1984

Date of Acceptance: 26 March 1985 